\title{
Firm Participation, Learning and Innovation in Heterogenous Value Chains of IT-enabled Services
}

Citation for published version (APA):

Keijser, C. (2019). Firm Participation, Learning and Innovation in Heterogenous Value Chains of ITenabled Services: The case of South Africa. [Doctoral Thesis, Maastricht University]. Boekenplan. https://doi.org/10.26481/dis.20190404ck

Document status and date:

Published: 01/01/2019

DOI:

10.26481/dis.20190404ck

Document Version:

Publisher's PDF, also known as Version of record

\section{Please check the document version of this publication:}

- A submitted manuscript is the version of the article upon submission and before peer-review. There can be important differences between the submitted version and the official published version of record.

People interested in the research are advised to contact the author for the final version of the publication, or visit the DOI to the publisher's website.

- The final author version and the galley proof are versions of the publication after peer review.

- The final published version features the final layout of the paper including the volume, issue and page numbers.

Link to publication

\footnotetext{
General rights rights.

- You may freely distribute the URL identifying the publication in the public portal. please follow below link for the End User Agreement:

www.umlib.nl/taverne-license

Take down policy

If you believe that this document breaches copyright please contact us at:

repository@maastrichtuniversity.nl

providing details and we will investigate your claim.
}

Copyright and moral rights for the publications made accessible in the public portal are retained by the authors and/or other copyright owners and it is a condition of accessing publications that users recognise and abide by the legal requirements associated with these

- Users may download and print one copy of any publication from the public portal for the purpose of private study or research.

- You may not further distribute the material or use it for any profit-making activity or commercial gain

If the publication is distributed under the terms of Article $25 \mathrm{fa}$ of the Dutch Copyright Act, indicated by the "Taverne" license above, 
Firm Participation, Learning and Innovation in Heterogeneous Value Chains of IT-enabled Services:

\section{The case of South Africa}

Charlotte Keijser

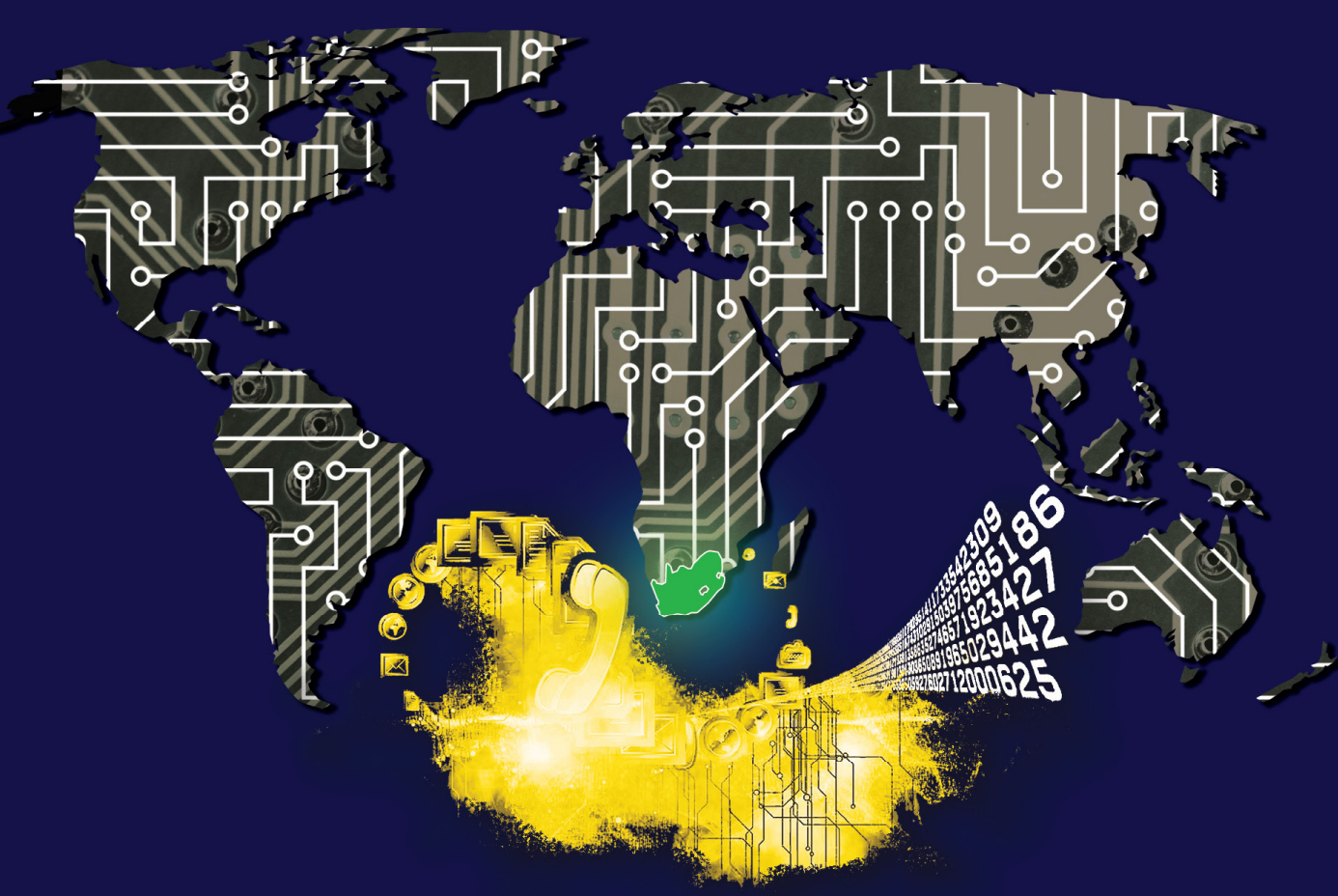

